\title{
Plasmodium and intestinal parasite perturbations of the infected host's inflammatory responses: a systematic review
}

\author{
Aminata Colle Lo ${ }^{1,2}$, Babacar Faye ${ }^{2}$, Ben Adu Gyan ${ }^{1}$ and Linda Eva Amoah ${ }^{{ }^{*}}$
}

\begin{abstract}
Co-infection of malaria and intestinal parasites is widespread in sub-Saharan Africa and causes severe disease especially among the poorest populations. It has been shown that an intestinal parasite (helminth), mixed intestinal helminth or Plasmodium parasite infection in a human induces a wide range of cytokine responses, including anti-inflammatory, pro-inflammatory as well as regulatory cytokines. Although immunological interactions have been suggested to occur during a concurrent infection of helminths and Plasmodium parasites, different conclusions have been drawn on the influence this co-infection has on cytokine production. This review briefly discusses patterns of selected cytokine (IL-6, IL-8, IL-10, TNF-a and INF- $\gamma$ ) responses associated with infections caused by Plasmodium, intestinal parasites as well as a Plasmodium-helminth co-infection.
\end{abstract}

\section{Background}

Malaria, a significant contributor to high childhood mortality, is endemic in the tropical regions as are pathogenic helminth infections. The distribution patterns of malaria parasites (Plasmodium spp.) and helminths coincide [1, 2], making malaria-intestinal parasite co-infections very common occurrences in most malaria endemic countries (Fig. 1, Table 1). In patients infected with Plasmodium spp., the interdependence between pro- and anti-inflammatory mediators of immunity can influence the survival of the Plasmodium parasite and subsequent development of disease [3]. In humans, helminth infections have strong immune-modulatory effects that could impact on other co-infecting parasites [4]. Additionally, helminth infections can cause anemia in the host. Anemia during a Plasmodium infection enhances gametocyte production [5], which can result in an increase in malaria transmission. Thus, an effective malaria control strategy should include critical knowledge of the impact helminth infections exert on Plasmodium parasite development and survival in the host.

\footnotetext{
*Correspondence: lamoah@noguchi.ug.edu.gh

${ }^{1}$ Noguchi Memorial Institute for Medical Research, University of Ghana, Accra, Ghana

Full list of author information is available at the end of the article
}

It is evident from several human epidemiological surveys that have assessed variations in cytokine responses during parasitic infections that contradictory findings have been reported on responses identified during Plasmodium-helminth co-infections. For example, some studies on co-infections of Plasmodium and selected helminths such as Schistosoma haematobium and Trichuris trichiura have reported an increase in malaria parasite prevalence, parasite density, frequency and severity of disease [6-10]. Other studies have suggested that co-infection with Plasmodium and selected helminths including Schistosoma mansoni or S. haematobium, Ascaris lumbricoides, Necator americanus and T. trichiura provides protection against malaria [11-13]. Some studies, however, could not identify any effect of helminth (S. haematobium and $S$. mansoni) co-infection on the outcome of malaria [14, 15]. Two recent meta-analyses determined the overall odds of asymptomatic malaria to be slightly lower in uninfected children compared to children infected with soil-transmitted helminths (STH), including, $N$. americanus, A. lumbricoides T. trichiura or $S$. mansoni or S. haematobium [16, 17]. It has, however, been noted that immune responses to the different forms (eggs, adults and cercariae) of helminths differ, such as the differences noted in inflammatory responses to S. mansoni eggs

(C) The Author(s). 2018 Open Access This article is distributed under the terms of the Creative Commons Attribution 4.0 International License (http://creativecommons.org/licenses/by/4.0/), which permits unrestricted use, distribution, and reproduction in any medium, provided you give appropriate credit to the original author(s) and the source, provide a link to the Creative Commons license, and indicate if changes were made. The Creative Commons Public Domain Dedication waiver (http://creativecommons.org/publicdomain/zero/1.0/) applies to the data made available in this article, unless otherwise stated. 


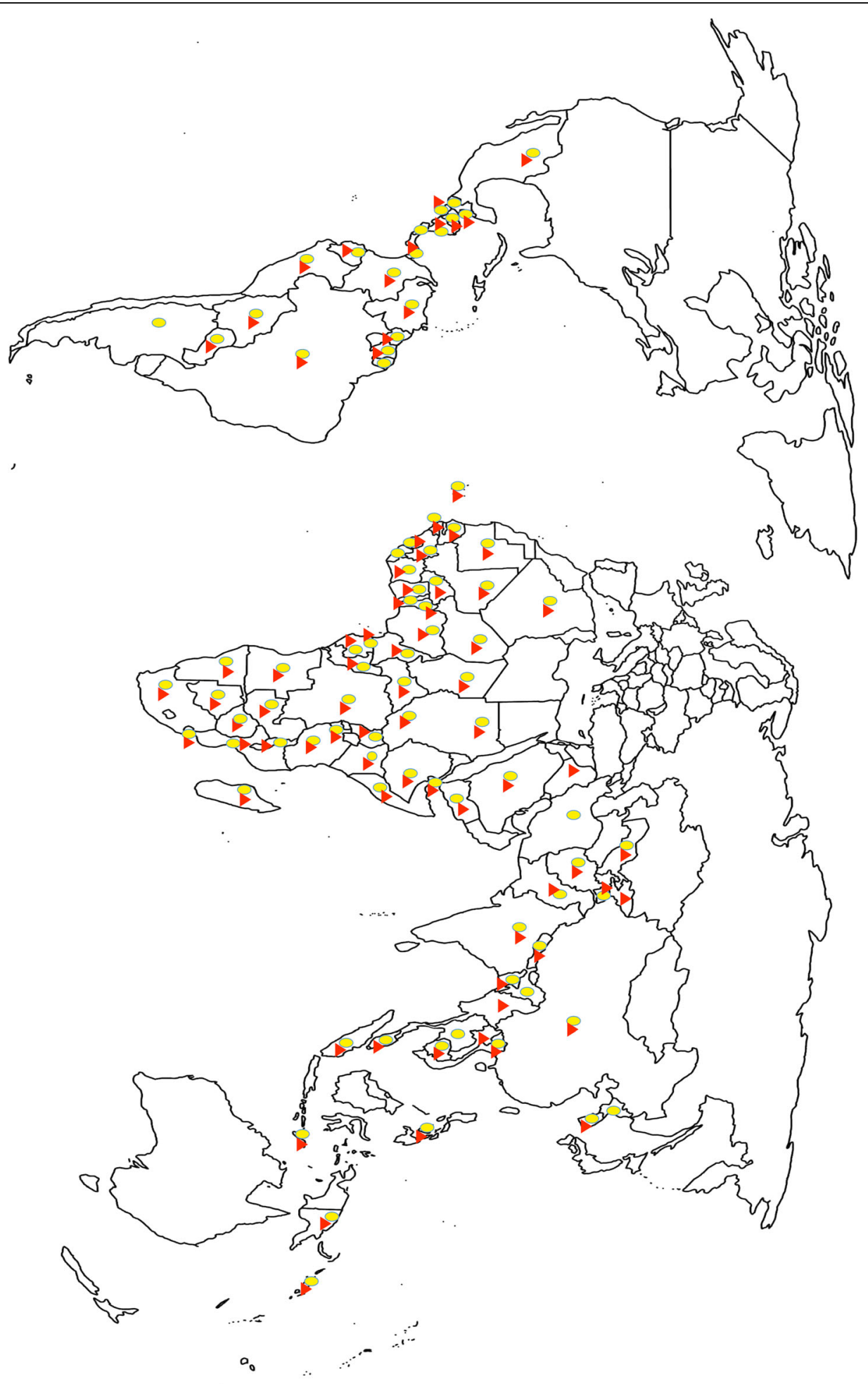

Fig. 1 Distribution of people suspected to have malaria and children with soil-transmitted helminthiases. A map showing the global distribution of people in 2016 with suspected malaria (ovals) and children requiring helminth treatment (triangles). Countries with both an oval and a triangle are burdened with both diseases. The data for the soil-transmitted helminthiases was obtained from the Global Health Observatory (GHO) data [2] and the suspected malaria cases obtained from the 2017 WHO Malaria Report [1]. 
and larvae [18]. As such immune responses during Plasmodium-helminth co-infections are naturally expected to differ, depending on the form (stage) of the infecting helminth (egg, larvae or adult). This then could account for the variations in results obtained in the reported studies. The risk of anemia has been suggested to be high in STH infections as is an increase in the prevalence of malaria during a Plasmodium-Schistosoma spp. co-infection [19]. During the 2-day life-cycle of the asexual Plasmodium falciparum parasite, some developmental life-stages

Table 1 Prevalence of Plasmodium-helminth co-infections. A selection of malaria-helminth co-infection prevalence data obtained from studies conducted in Africa and South America

\begin{tabular}{|c|c|c|c|}
\hline Country & Year & Prevalence (\%) & Reference \\
\hline Cameroon & 2008 & 13.9 & {$[127]$} \\
\hline Cameroon & 2014 & 22.1 & {$[128]$} \\
\hline Cameroon & 2015 & 11.9 & [129] \\
\hline Cameroon & 2016 & 11.6 & {$[16]$} \\
\hline Colombia & 2012 & 24.5 & [130] \\
\hline Ethiopia & 2009 & 23.6 & [131] \\
\hline Ethiopia & 2010 & 39.6 & [132] \\
\hline Ethiopia & 2012 & 19.4 & [133] \\
\hline Ethiopia & 2012 & 5.2 & [134] \\
\hline Gabon & 2010 & 15.0 & [135] \\
\hline Ghana & 2009 & 31.0 & [136] \\
\hline Ghana & 2009 & 30.7 & {$[9]$} \\
\hline Ghana & 2011 & 30.5 & [137] \\
\hline Indonesia & 2016 & 7.1 & [138] \\
\hline Ivory Coast & 2012 & 24.7 & [139] \\
\hline Ivory Coast & 2014 & 13.5 & [140] \\
\hline Kenya & 2008 & 26.7 & [141] \\
\hline Kenya & 2009 & 37.8 & [142] \\
\hline Kenya & 2011 & 0.9 & [143] \\
\hline Kenya & 2013 & 4.7 & [144] \\
\hline Kenya & 2015 & 14.3 & [145] \\
\hline Malawi & 2011 & 21.4 & [146] \\
\hline Nigeria & 2011 & 4.3 & [147] \\
\hline Nigeria & 2013 & 20.9 & [148] \\
\hline Nigeria & 2013 & 42.9 & [149] \\
\hline Tanzania & 2014 & 17.9 & [150] \\
\hline Tanzania & 2017 & 26.4 & [151] \\
\hline Thailand & 2010 & 19.0 & [13] \\
\hline Uganda & 2005 & 54.8 & {$[86]$} \\
\hline Uganda & 2008 & 15.5 & [152] \\
\hline Uganda & 2010 & 15.5 & [153] \\
\hline Uganda & 2011 & 9.3 & [143] \\
\hline Zambia & 2012 & 44.3 & [154] \\
\hline
\end{tabular}

(trophozoites and schizonts) are sequestered and evade immune recognition [20]. The 3 to 13 week helminth (varies for specific helminthes) life-cycle in the human similarly goes through various developmental stages, each eliciting variations in immune responses in the human host [21]. This makes the timing and order in which a parasitic mono-infection becomes a co-infection additional contributing factors that could account for the disparities in immune responses reported during Plasmodium-helminth co-infections.

\section{Cytokines associated with malaria infections}

During a Plasmodium infection, T-cell mediated inflammatory responses contribute to reduced parasite density as well as the pathology of the disease [22,23]. The mechanism by which the host controls parasite density via regulating inflammatory processes remains poorly understood [24], although a number of human and animal studies have suggested that the extent to which the host regulates the level and longevity of inflammatory responses generated against the parasite governs the efficient clearance of the parasite during the infection [25]. An optimum balance of cytokines is always needed at the different stages of the infection [26] to ensure effective parasite clearance. Pro-inflammatory responses such as IL-12, IFN- $\gamma$ and TNF- $\alpha$ are Th1 cytokines, which are predominantly expressed during a Plasmodium infection in both humans and small rodents [27]. The Th1 cytokines including IL-6, IL-8, IL-12 and TNF- $\alpha$ are produced by a number of different cells including macrophages, dendritic cells and antigen presenting cells [28] are crucial to regulating parasite density at the beginning of a $P$. falciparum infection $[29,30]$.

\section{Systemic cytokines associated with human malaria}

An acute $P$. falciparum infection is usually associated with an increase in pro-inflammatory responses, which subsequently cause an increase in the secretion of IFN- $\gamma$ and TNF- $\alpha$ [31]. An early IFN- $\gamma$ response is crucial in protecting against the development of the symptoms associated with severe malaria [32-34]. However, during a chronic $P$. falciparum infection, cytokines including IL-12, IFN- $\gamma$ and TNF- $\alpha$ can induce adverse immunopathology if not well regulated [35]. The induction and expansion of regulatory $\mathrm{T}$ (Treg) cells are crucial during chronic disease [25, 36, 37] because Th2 cytokine cells can counteract Th1 responses.

A study conducted on the Dogon and the Fulani people of Mali, who live within the same environment but respond very differently to $P$. falciparum infections (Fulani are more resistant to malaria than the Dogon), found that IL-6, IL-8, IL-12 and IFN- $\gamma$ levels in uninfected Fulani children were much higher than in uninfected Dogon children. The levels of IL-8 in Fulani 
infected with $P$. falciparum were significantly lower than an uninfected Fulani; however, the same was not observed among the Dogon people. They also identified IFN- $\gamma$ as the only cytokine that was significantly higher in $P$. falciparum-infected Fulani children compared to matched Dogon children [38]. Stimulation of mononuclear cells from a Fulani with Plasmodium parasites was found to produce 10-times higher IFN- $\gamma$ responses compared to similar cells from the Dogon [38].

TNF- $\alpha$ is predominantly secreted by activated macrophages and its pyrogenic properties are central to the immune response generated during a Plasmodium infection [39]. IL-6 has been suggested to be an essential component of the immune response during the acute phase [40] and in complicated $P$. falciparum malaria [41]. Elevated levels of IL-6 have also been associated with an increase in the incidence of clinical malaria [41]. This suggests that the IL- 8 contribution to protection may be specific to the Fulani, especially as elevated levels of IL- 8 have been reported in adults with severe malaria in Thailand [42]. Additional studies are needed to clarify the roles of IL-6 and IL-8 during Plasmodium infections.

Interleukin 10 in combination with other cytokines play an important role as immune regulators by neutralizing the Th1 effects associated with the more severe forms of Plasmodium infection [35]. Plasma levels of IL-10 in children with asymptomatic and mild malaria were found to correlate positively with the parasite load and to reduce significantly after the parasites in the peripheral blood were cleared [43]. Elevated levels of IL-10 with low TNF- $\alpha$ have been associated with mild malaria [43], whilst recovery from malaria (parasite clearance) has been associated with reduced levels of IL-10 [44]. Similarly, IL-10 levels in Zambian children under six years-old with severe malaria anemia were not significantly associated with protection [45]. The development of severe malaria anemia in African children may be a result of a lack of IL-10 production in response to high TNF- $\alpha$ concentrations [46]. Furthermore, increased IL-10 but not IL-12 production has been associated with increased parasite density in Mozambican children with both severe and uncomplicated malaria [47].

\section{Cytokines associated with murine malaria}

Animal studies have been used to buttress some findings observed in in vitro and in vivo human studies relating to the use of cytokines in the control of malaria parasites. Murine models of malaria demonstrate a regulation of balance between IL-10 and inflammatory cytokines such as IFN- $\gamma$ and TNF- $\alpha$ [48]. IL-10 production early in a rodent malaria infection has been found to prevent high parasite loads due to reduced Th1 responses [48] and the absence of regulatory cytokines during the later stages of the infection resulted in the development of adverse immuno-pathology [48]. Although pro-inflamatory responses involving cytokines including TNF- $\alpha$, IFN- $\gamma$ have been identified as contributors to the pathology of cerebral malaria in mice [49], early production of IFN- $\gamma$ has been found to be crucial for preventing cerebral malaria [50].

In summary, human and murine models have both suggested IFN- $\gamma$ to be essential for parasite clearance and reduced parasite multiplication rates [51-53]. However, regulated IFN- $\gamma$ levels are required to avoid immune pathology $[26,39]$. These characteristics of IFN- $\gamma$ suggest it to be an ideal marker for tolerance to Plasmodium infections. Increased levels of IFN- $\gamma$, TNF- $\alpha$, IL-12 and IL-10 are known to be associated with a reduced risk of malaria; however, those who become infected with malaria parasites have an elevated risk of symptomatic malaria [54]. These cytokines are also essential for inhibiting parasite development, stimulating parasite clearance and interacting with macrophages, which amongst other processes control infections through antibody-dependent and independent phagocytosis [55]. These subsequently resulted in the suppression of merozoite invasion into erythrocytes and subsequently fewer parasitized erythrocytes. More information on processes that occur in the immune system during a Plasmodium parasite infection can help develop malaria vaccines as well as help in designing other strategies for malaria control interventions such as intermittent preventive treatment (IPT) or seasonal malaria chemoprevention (SMC).

\section{Effects of intestinal parasite infections on cytokine profiles}

Helminths survive by modulating the host's immune system [17]. The initial immune response to intestinal helminths is usually Th1, which is then overtaken by Th2 during the course of the infection. Elevated Th2 response $[56,57]$ and the production of a regulatory network of immune responses [58, 59] are hallmarks of chronic helminthiasis that have the potential to impact the host's immune response to other antigens [60]. The chronic immune activation caused by a helminth infection can alter T-cell memory responses and result in altered Th1 responses $[18,61,62]$. However, some intestinal helminth interactions with the host, such as host skin penetration by schistosome cercariae released from the intermediate host (a snail) induce strong Th1 responses. These responses make the host susceptible to inflammation characterized by the production of TNF- $\alpha$ together with other cytokines such as IL-1, IL-8, IFN- $\gamma$ $[63,64]$. TNF- $\alpha$ has been reported to enhance $[65,66]$ as well as decrease [67] the egg laying properties of female $S$. mansoni parasites. The role played by TNF- $\alpha$ 
in the metabolism of the adult S. mansoni parasite also remains controversial [68]. A comprehensive description of the processes involved in the TNF- $\alpha$ pathway in helminths is not readily available.

Although concurrent multiple (mixed) helminth infections are frequent occurrences, little is known about how concurrent parasite infections, such as S. mansoni, S. haematobium and A. lumbricoides, influence immune responses in a patient. There are only a few studies that have tried to understand the effect of multiple helminths and intestinal protozoan parasite co-infections on immune responses in children [69-71]. The IL-10 levels of children infected with mono or mixed helminths have been found to be similar to the levels in uninfected children; however anthelmintic treatment of the infected children resulted in a significant reduction in IL-10 levels compared to the uninfected children [70]. Similarly, when peripheral blood mononuclear cells (PBMCs) from adults co-infected with three parasites (filaria, hookworm and Entamoeba histolytica) were stimulated with helminth-specific antigens, they produced higher IL-10 levels compared with PBMCs from adults without the triple infection [72]. Filarial infection in Malian children aged between 11 and 17 years was found to have a higher ex vivo frequency of CD4+ cells producing IL-10 and IL-4 compared with those without the infection [73]. IL-10 can modulate Th1 responses by reducing pro-inflammatory cytokine, including TNF- $\alpha$, IFN- $\gamma$ and IL-12 responses [72] as well as enhancing immune suppression by preventing symptoms of inflammation $[74,75]$. An increase in IL-10 levels may generate chronic disease pathogenesis. Co-infection with different helminths may counteract the IL-10 effect and the distinct cytokine response profiles generated may be used to define immunity as well as the severity of the resultant disease $[68,76]$. A chronic co-infection of Brazilian children aged between 4 and 11 years with $A$. lumbricoides and T. trichiura was associated with an acute production of IL-10 in response to stimulation with $A$. lumbricoides antigen [77]. However, another study in young adults similarly co-infected with $A$. lumbricoides and T. trichiura, identified similar levels of IL-10 in the uninfected control, the mono- and poly-parasite infected groups [78]. The balance between Th1 and Th2 immune responses induced in a host during a multiple mixed intestinal parasite infection can hinder immune clearance of one of the co-infecting parasites over the other as has been suggested from a study on young children within independent or co-infections with Giardia lamblia and Ascaris lumbricoides. Higher levels of TNF- $\alpha$ was found in the co-infected children compared to matched children with only a Giardia infection and the IL-10/IFN- $\gamma$ ratio in these co-infected children was higher than in uninfected children as well as children with only an
Ascaris infection [79]. These results suggest that although the host most often is able to control infecting helminth load by initiating Th2 cytokine production, the presence of concurrent intestinal parasites can alter the cytokine responses and lead to persistence or a chronic infection of one of the infecting parasites.

\section{Cytokine profile during co-infection of Plasmodium and intestinal parasites}

The precise impact of polyparasitism on the immunopathology of malaria is not known even though malaria co-infections with intestinal parasites in tropical regions are common [4]. Several studies conducted in Africa demonstrate that infection with STH and Schistosoma spp. may affect the immune response of a host to a malaria parasite infection and lead to increased susceptibility and disease severity [80-83]. However, helminthic infections have also been demonstrated to offer protection against severe malaria and anemia [84]. The variations reported in these study outcomes could be due to differences in the co-infecting helminth species, study design, study population and the level of immunity to Plasmodium parasites in the study population $[85,86]$.

Ascaris infections are more likely to afford protection against severe malaria while infections with hookworm or Schistosoma spp. are more likely to enhance the incidence of malaria [87]. The underlying immune responses generated against the different pathogens may have a strong effect on the development and pathological consequences of malaria. Diallo et al. [82] reported higher plasma levels of TNF- $\alpha$ and IFN- $\gamma$ in S. haematobium and $P$. falciparum co-infected children compared with those infected with only $P$. falciparum. When blood from Ghanaian children with and without a S. haematobium infection was stimulated with $P$. falciparum antigens, a significantly higher level of IL-10 was recorded [17]. Similarly, IL-10 levels were significantly increased and INF- $\gamma$, IL-17 and TNF- $\alpha$ marked decreased when whole blood samples from asymptomatic malaria patients in Mali with filaria co-infections were stimulated with $P$. falciparum schizont lysate compared with the asymptomatic patients without filarial infection [73]. Children aged between 4 and 14 years with malaria and an asymptomatic $S$. haematobium infection were found to have significantly higher levels of IFN- $\gamma$ but similar levels of IL-10 when compared to matched children without S. haematobium infection [88]. Schistosoma haematobium was found to protect against $P$. falciparum in children between 4 and 8 years-old [88]. IL-6 and IL-10 levels were found to correlate positively with acute malaria in children infected with $S$. haematobium who developed $P$. falciparum malaria when compared with Schistosoma-negative children who developed malaria. The effect was more pronounced in children aged 
between 9 and 14 years relative to those between 4 and 8 years [89]. Whilst a similar IL-10/IFN- $\gamma$ ratio was observed in both the Schistosoma-positive and -negative children aged between 4 and 14 years who developed acute malaria, a significantly lower mean IL-10/TNF- $\alpha$ ratio was identified in Schistosoma-positive children aged between 9 and 14 years who developed acute malaria compared with matched Schistosoma negative children [89]. However, results from a study involving children co-infected with Plasmodium and S. haematobium did not demonstrate any influence of the co-infecting helminth on the immune response generated by the host against the Plasmodium parasite as a similar increase in both innate and adaptive immune responses was observed in the P. falciparum-infected and P. falciparum-S. haematobium co-infected children [90].

Helminth infections induce immuno-regulatory responses such as Th2 responses in the human host. These immune-regulatory responses can inhibit the ability of the host to mount an effective Th1 response [78], which also influences the immune response against the malaria parasite. When plasma levels of cytokines from individuals from the Amazon region of Brazil with either a Plasmodium infection or an intestinal parasite (G. intestinalis, A. duodenale and S. stercoralis) infection or concurrent Plasmodium-helminth (G. intestinalis, A. duodenale and $S$. stercoralis) co-infection were compared to uninfected individuals, the levels of TNF- $\alpha$, IL-2, IL-10, IL- 6 in the Plasmodium and Plasmodium-helminth co-infected group were similar, and both significantly higher than the uninfected group. These results corroborated the absence of additional stimulation of cytokine responses by the co-infecting helminth [91]. The median level of IFN- $\gamma$ was, however, increased in all three (Plasmodium, intestinal parasite and Plasmodium-helminth co-infected) groups compared to the uninfected group [91]. In malaria, an efficient immunological balance prevents excessive multiplication of the parasite, which enables the malaria parasite survive in the host without the associated activation of inflammation. More studies are however needed to elucidate the immunological balance and the relationship between Th1, Th2 and chemokine responses that develop and moderate a Plasmodium-helminth co-infection as such information is very limited.

\section{Cytokine profile in pregnancy during a malaria and intestinal parasite co-infection}

Pregnancy naturally causes alterations in immune responses and results in the dominance of Th2 immune responses. Increased IL-10 and a decrease in IFN- $\gamma$ production have been associated with successful pregnancies in humans [92-94]. However, decreased IFN- $\gamma$ and TNF- $\alpha$ production in animal models have been associated with poor pregnancy outcomes $[93,94]$. These alterations in immune responses have been found to alter the susceptibility of pregnant women to some infectious diseases [95] including malaria [96, 97] and intestinal parasite infections $[98,99]$. In humans, IFN- $\gamma$ levels to schistosome egg and worm antigen has been found to decrease during pregnancy and high IL-10 levels [100-102] as well as IFN- $\gamma$, TNF- $\alpha$, IL-10 and IL-6 [103] have been found to be associated with pregnancy associated malaria. Animal models have also shown a reduced schistosome specific IFN- $\gamma$ production in pregnant mice [104]. Interleukin 10 responses to schistosome egg and worm antigen, however, are not altered by pregnancy in humans $[105,106]$. The alterations in cytokine responses during the individual mono parasitic infections are likely to influence cytokine responses that occur during Plasmodium-helminth co-infections [98]. Although a number of studies have been conducted on pregnant women co-infected with Plasmodium and helminths, their main focus, which has been captured in a review by Mpairwe et al. [107], has been on anemia and birth outcomes, including infant birth weight, anemia, mortality and response to vaccines amongst others. More studies are needed to monitor changes in immune responses that occur across the three trimesters of pregnancy in women co-infected with these parasites as pregnancy makes women highly susceptible to mono and co-infections of these parasitic infections.

\section{Insights}

We noticed the existence of several disparities relating to the association between various cytokine levels found in individuals co-infected with $P$. falciparum and different helminths. Diverse effects of a helminth infection on the susceptibility, severity and the pathology or the risk of cerebral malaria have been observed in several human studies conducted in Africa. These disparities could have arisen as a result of a number of different covariates, including the choice and nutritional status of the cohort(s) used in the study, the level of exposure, the infecting parasite species and the population and composition of microbial communities (microbiota) resident in the hosts' intestines to name a few. In P. falciparum immunology, age is a strong confounder to antibody and cytokine analysis; however, in many of the studies monitoring the cytokine profiles of people with a malaria helminth co-infection, children with ages ranging from a few months with a low age range [91], to 19 years with a large age range [108] were used. TNF- $\alpha$ was found to be generally high in children aged between 11 and 12 years irrespective of their infection status. More consistent data could be obtained when the categories of age stratification is better described.

The definition of a P. falciparum and helminth infection differed between the studies, making the definition for a malaria helminth co-infection very different. A few 
studies defined malaria as $P$. falciparum positivity by real time PCR [89] and others used microscopy [89, 109]. Some studies defined a helminth infection as parasite positivity by real time PCR [91] or by observing eggs in stool and urine using microscopy $[89,91]$. The sensitivity of the tests applied could interfere with sample grouping and subsequently influence the statistical analysis. In some instances, the cohort was asymptomatic for one [110] or both [91] the malaria and helminth infection. Other times, one infection was classified as symptomatic and sometimes chronic. A better understanding of cytokine responses generated during different presentations of an infection, such as during asymptomatic and symptomatic as well as high and low density infections, especially relating to malaria, could also help in providing a more stringent interpretation of and less disparity in the data obtained during Plasmodium-helminth co-infections under different infecting parasite conditions.

Nutrition directly impacts immunity as malnutrition and obesity have been found to result in immunodeficiency and reduced immunity, respectively [111], and indirectly influence the composition of resident microbiota in the host. Microbiota that colonize the human intestine have been found to regulate, including the modulation of $\mathrm{T}$ cell differentiation $[112,113]$ as well as be regulated by the human immune system [114]. Disruption of the homeostatic balance between the microbiota and the immune system can render the host susceptible to disease [115]. Animal studies have identified helminth infections to alter the microbiota composition in the infected animal and subsequently result in an increase in the adult worm population [116]. Luckily, the alteration in microbiota composition is reversible, with elimination of the adult helminth resulting in a restoration of the original microbiota composition [117] as well as immunity of the previously infected host. Controlling for nutritional status and resident microbiota population and composition within and between cohorts would be very challenging and as such would remain as an uncontrollable covariate.

These properties of the infection status all greatly influence the cytokine profile of the individual infections and likely would affect the cytokine profile of the co-infection. A list of cytokine responses associated with

Table 2 Changes in cytokine profiles during parasitic infections. A selection of results obtained from selected Plasmodium, helminth and Plasmodium-helminth co-infection studies conducted in Africa and South America

\begin{tabular}{|c|c|c|c|c|c|}
\hline Year & Country & $\begin{array}{l}\text { Study } \\
\text { population }\end{array}$ & Parasite & Cytokines & Reference \\
\hline 2016 & Indonesia & $\begin{array}{l}\text { All age } \\
\text { groups }\end{array}$ & Helminths & $\begin{array}{l}\text { Increased in vitro production of pro-inflammatory cytokines in response } \\
\text { to Pf after treatment }\end{array}$ & [108] \\
\hline 2015 & Gabon & Children & Schistosoma haematobium & $\begin{array}{l}\text { Innate or adaptive immune response to } P f \text { with or without Schistosoma } \\
\text { co-infection was similar }\end{array}$ & [90] \\
\hline \multirow[t]{3}{*}{2015} & Kenya & Children & Polyparasite & $\begin{array}{l}\text { IL-10 increased with Schistosoma infection but decreased in Schistosomal } \\
\text { filaria co-infections }\end{array}$ & [90] \\
\hline & & & & $\begin{array}{l}\text { IL-6 increased with Pf infection but decreased in Pfhookworm } \\
\text { co-infection }\end{array}$ & [109] \\
\hline & & & & IL-6 and TNF-a levels were not affected by Schistosoma infection & [109] \\
\hline 2014 & Nigeria & Children & Schistosoma haematobium & $\begin{array}{l}\text { IL-10 did not change with Schistosoma infection but IFN- } \gamma \text { increased in } \\
\text { older children }\end{array}$ & [110] \\
\hline 2014 & Brazil & $\begin{array}{l}\text { All age } \\
\text { groups }\end{array}$ & $\begin{array}{l}\text { Giardia intestinalis, Ancylostoma } \\
\text { duodenale, Strongiloides } \\
\text { stercoralis }\end{array}$ & $\begin{array}{l}\text { TNF-a, IL-12, IL-10 and IL-6 were low but IFN- } \gamma \text { was high in co-infected } \\
\text { people }\end{array}$ & [91] \\
\hline 2013 & Ghana & $\begin{array}{l}\text { All age } \\
\text { groups }\end{array}$ & $\begin{array}{l}\text { Necator americanus and } \\
\text { Giardia lamblia }\end{array}$ & Pf exposure increased TNF- $a, I L-17$ and IL-7 production & [155] \\
\hline 2012 & Mali & Children & Schistosoma haematobium & Higher Th1 cytokines in Schistosoma/Pf co-infections & {$[88]$} \\
\hline 2012 & Mali & $\begin{array}{l}\text { All age } \\
\text { groups }\end{array}$ & Filaria & $\begin{array}{l}\text { IL-12 low in filarial-positive, in vitro filarial-positive associated with IFN } \\
\text { regulatory factor } 1 \text {, no IL-12 in response to malaria antigen stimulation }\end{array}$ & [156] \\
\hline 2011 & Mali & $\begin{array}{l}\text { All age } \\
\text { groups }\end{array}$ & Filaria & $\begin{array}{l}\text { Filarial infection with asymptomatic malaria was associated with an } \\
\text { increase in IL-4, IL-10 and IL-17A. PBMC stimulation with Pf antigen } \\
\text { reduced IFN- } \gamma \text {, TNF-a and IL-17A in the filiarial infection }\end{array}$ & [73] \\
\hline 2011 & Senegal & $\begin{array}{l}\text { All age } \\
\text { groups }\end{array}$ & Schistosoma haematobium & Higher IL-10 in the co-infected group & {$[157]$} \\
\hline 2010 & Senegal & Children & Schistosoma haematobium & Schizont extract produced IL-10 only in co-infected group & [158] \\
\hline 2009 & $\begin{array}{l}\text { West } \\
\text { Kenya }\end{array}$ & Children & Schistosoma mansoni & Memory T-regulators cells decreased in co-infected children & [159] \\
\hline
\end{tabular}


the innate and adaptive immune responses to Plasmodium and helminth infections and co-infections is shown in Table 2.

Anthelmintic treatment (deworming) in humans has been suggested to enhance immune responsiveness to vaccines, especially to Plasmodium antigens in adults and children above 4 years old [118]. A major stumbling block to the validation of a malaria vaccine candidate is reduced immunogenicity. Currently, the only licensed malaria vaccine $(\mathrm{RTS}, \mathrm{S})$ is recommended to be administered as a four dose schedule in infants between 5 and 17 months old, which exhibited a $31.5 \%$ efficacy against severe malaria over a four year period [119]. Deworming children between 5 and 17 months is likely to result in enhanced immune responsiveness to the Plasmodium antigen (circumsporozoite protein, CSP) in RTS,S and subsequently increase the effectiveness of the vaccine. This increased immune responsiveness may also result in RTS,S efficacy in older children as well.

Experimental results obtained from the mice studies discussed in this review that have not been validated in human studies are to be taken as suggestive and to an extent that is probable but not definitive. These cautions are relevant because despite the genetic and physciological similarities between humans and mice $[120,121]$ and the fact that some studies have demonstrated similarities in observations made in both murine and human studies [122-124]. A number of studies have demonstrated disparities in results from murine and human studies such as fibrogenesis in mice being associated with a Th2 response but fibrogenesis caused by severe 'hepatio-splenic' schistosomiasis in humans associated with Th1 responses $[125,126]$.

\section{Conclusions}

Several studies have provided evidence of immunological perturbations occurring during Plasmodium intestinal parasite co-infections; however, due to varying confounding factors, different mechanisms have been reported for the protection provided by different cytokines. A major source of variation in the results reported by the numerous studies could be the use of different cohorts and population (ethnic groups and age), stimulant (live parasite or recombinant antigen) and cell type (PBMC or plasma) as well as the different methods used to determine parasite prevalence and density.

Increased national efforts to reduce parasitic worm infections with frequent mass drug treatments may result in the modulation of the helminth induced cytokine response. It is thus imperative that the precise contribution intestinal parasites add on to immune responses generated during a malaria infection is fully understood. This will enable a better understanding of immune modulation when such a mass drug treatment is implemented. Increased efforts to obtain an effective malaria vaccine require a complete understanding of immune moderations generated during the co-infections of Plasmodium and intestinal worms.

\section{Abbreviations \\ IL: Interleukin; INF-Y: Interferon gamma; STH: Soil-transmitted helminths; TNF- a: Tumor necrosis factor}

\section{Acknowledgements}

The authors thank the Bill and Melinda Gates Foundation through the postdoctoral training in Infectious Diseases at Noguchi Memorial Institute for Medical Research, Ghana (Global Health Grant number OPP52155) awarded to ACL. We also thank Dickson Donu and Dr Patience Borkor Tetteh-Quarcoo for help with the co-infection map.

\section{Authors' contributions}

$A C L$ and $L E A$ wrote the manuscript; $L E A, B G$ and $B F$ edited the manuscript. All authors read and approved the final manuscript.

Ethics approval and consent to participate

Not applicable.

Consent for publication

Not applicable.

Competing interests

The authors declare that they have no competing interests.

\section{Publisher's Note}

Springer Nature remains neutral with regard to jurisdictional claims in published maps and institutional affiliations.

\section{Author details}

${ }^{1}$ Noguchi Memorial Institute for Medical Research, University of Ghana, Accra, Ghana. ${ }^{2}$ University Cheikh Anta DIOP, Dakar, Senegal.

Received: 26 January 2018 Accepted: 12 June 2018

Published online: 03 July 2018

\section{References}

1. WHO. World Malaria Report 2017. In: World Malaria Report. Geneva: WHO; 2017.

2. WHO. Soil-transmitted helminthiases. In: PCT databank. Edited by data GHOG. Geneva: WHO; 2017.

3. Clark IA, Alleva LM, Budd AC, Cowden WB. Understanding the role of inflammatory cytokines in malaria and related diseases. Travel Med Infect Dis. 2008;6:67-81.

4. Pullan $\mathrm{R}$, Brooker $\mathrm{S}$. The health impact of polyparasitism in humans: are we under-estimating the burden of parasitic diseases? Parasitology. 2008;135:783-94.

5. Price R, Nosten F, Simpson JA, Luxemburger C, Phaipun L, Ter Kuile F, et al. Risk factors for gametocyte carriage in uncomplicated falciparum malaria. Am J Trop Med Hyg. 1999;60:1019-23.

6. Nacher M. Worms and malaria: blind men feeling the elephant? Parasitology. 2008;135:861-8

7. Friis H, El Karib SA, Sulaiman SM, Rahama A, Magnussen P, Mascie-Taylor CGN. Does Schistosoma haematobium coinfection reduce the risk of malaria-induced splenomegaly? Trans R Soc Trop Med Hyg. 2000;94:535-6.

8. Florey LS, King CH, Van Dyke MK, Muchiri EM, Mungai PL, Zimmerman PA, et al. Partnering parasites: evidence of synergism between heavy Schistosoma haematobium and Plasmodium species infections in Kenyan children. PLoS Negl Trop Dis. 2012;6:e1723.

9. Yatich NJ, Yi J, Agbenyega T, Turpin A, Rayner JC, Stiles JK, et al. Malaria and intestinal helminth co-infection among pregnant women in Ghana: prevalence and risk factors. Am J Trop Med Hyg. 2009;80:896-901.

10. Chaorattanakawee S, Natalang O, Hananantachai H, Nacher M, Brockman A, Nosten F, et al. Trichuris trichiura infection is associated with the multiplicity of Plasmodium falciparum infections, in Thailand. Ann Trop Med Parasitol. 2003;97:199-202. 
11. Hillier SD, Booth M, Muhangi L, Nkurunziza P, Khihembo M, Kakande M, et al. Plasmodium falciparum and helminth coinfection in a semi urban population of pregnant women in Uganda. J Infect Dis. 2008;198:920-7.

12. Lyke KE, Dicko A, Dabo A, Sangare L, Kone A, Coulibaly D, et al. Association of Schistosoma haematobium infection with protection against acute Plasmodium falciparum malaria in Malian children. Am J Trop Med Hyg. 2005;73:1124-30

13. Boel M, Carrara VI, Rijken M, Proux S, Nacher M, Pimanpanarak M, et al. Complex interactions between soil-transmitted helminths and malaria in pregnant women on the Thai-Burmese border. PLoS Negl Trop Dis. 2010;4:e887.

14. Midzi N, Sangweme D, Zinyowera S, Mapingure MP, Brouwer KC, Munatsi A, et al. The burden of polyparasitism among primary schoolchildren in rural and farming areas in Zimbabwe. Trans R Soc Trop Med Hyg. 2008;102:1039-45.

15. Mboera LE, Senkoro KP, Rumisha SF, Mayala BK, Shayo EH, Mlozi MR. Plasmodium falciparum and helminth coinfections among schoolchildren in relation to agro-ecosystems in Mvomero District, Tanzania. Acta Trop. 2011; 120:95-102.

16. Kwenti TE, Nkume FA, Tanjeko AT, Kwenti TDB. The effect of intestinal parasitic infection on the clinical outcome of malaria in coinfected children in Cameroon. PLoS Negl Trop Dis. 2016;10:e0004673.

17. Hartgers FC, Yazdanbakhsh M. Co-infection of helminths and malaria: modulation of the immune responses to malaria. Parasite Immunol. 2006;28:497-506.

18. Pearce EJ, Caspar P, Grzych J-M, Lewis FA, Sher A. Downregulation of Th1 cytokine production accompanies induction of Th2 responses by a parasitic helminth, Schistosoma mansoni. J Exp Med. 1991;173:159-66.

19. Nacher M, Singhasivanon P, Gay F, Phumratanaprapin W, Silachamroon U, Looareesuwan S. Association of helminth infection with decreased reticulocyte counts and hemoglobin concentration in Thai falciparum malaria. Am J Trop Med Hyg. 2001;65:335-7.

20. David P, Hommel M, Miller L, Udeinya J, Oligino L. Parasite sequestration in Plasmodium falciparum malaria: spleen and antibody modulation of cytoadherence of infected erythrocytes. Proc Natl Acad Sci USA. 1983;80:5075-9.

21. Gause WC, Urban JF Jr, Stadecker MJ. The immune response to parasitic helminths: insights from murine models. Trends Immunol. 2003;24:269-77.

22. Palomo J, Fauconnier M, Coquard L, Gilles M, Meme S, Szeremeta F, et al. Type I interferons contribute to experimental cerebral malaria development in response to sporozoite or blood-stage Plasmodium berghei ANKA. Eur J Immunol. 2013;43:2683-95.

23. Villegas-Mendez A, Greig R, Shaw TN, de Souza JB, Findlay EG, Stumhofer JS, et al. IFN- - -producing CD4+ T cells promote experimental cerebral malaria by modulating CD8+ T cell accumulation within the brain. J Immunol. 2012; 189:968-79.

24. Finney OC, Riley EM, Walther M. Regulatory T cells in malaria - friend or foe? Trends Immunol. 2010;31:63-70.

25. Finney OC, Nwakanma D, Conway DJ, Walther M, Riley EM. Homeostatic regulation of $\mathrm{T}$ effector to Treg ratios in an area of seasonal malaria transmission. Eur J Immunol. 2009:39:1288-300.

26. Artavanis-Tsakonas K, Tongren JE, Riley EM. The war between the malaria parasite and the immune system: immunity, immunoregulation and immunopathology. Clin Exp Immunol. 2003;133:145-52.

27. Noone C, Parkinson M, Dowling DJ, Aldridge A, Kirwan P, Molloy SF, et al. Plasma cytokines, chemokines and cellular immune responses in pre-school Nigerian children infected with Plasmodium falciparum. Malar J. 2013;12:5.

28. Blanco P, Palucka AK, Pascual V, Banchereau J. Dendritic cells and cytokines in human inflammatory and autoimmune diseases. Cytokine Growth Factor Rev. 2008;19:41-52.

29. Su Z, Segura M, Morgan K, Loredo-Osti JC, Stevenson MM. Impairment of protective immunity to blood-stage malaria by concurrent nematode infection. Inf Immun. 2005;73:3531-9.

30. Doolan DL, Dobaño C, Baird JK. Acquired immunity to malaria. Clin Microbiol Rev. 2009:22:13-36

31. Clark IA, Budd AC, Alleva LM, Cowden WB. Human malarial disease: a consequence of inflammatory cytokine release. Malar J. 2006;5:85

32. Cabantous S, Poudiougou B, Traore A, Keita M, Cisse MB, Doumbo O, et al. Evidence that interferon- $\gamma$ plays a protective role during cerebral malaria. J Inf Dis. 2005;192:854-60.

33. Perlaza B-L, Sauzet J-P, Brahimi K, BenMohamed L, Druilhe P. Interferon- $\gamma$, a valuable surrogate marker of Plasmodium falciparum pre-erythrocytic stages protective immunity. Malar J. 2011;10:27.

34. D'Ombrain MC, Robinson LJ, Stanisic DI, Taraika J, Bernard N, Michon P, et al. Association of early interferon-gamma production with immunity to clinical malaria: a longitudinal study among Papua New Guinean children. Clin Infect Dis. 2008:47:1380-7.

35. Day NPJ, Hien TT, Schollaardt T, Loc PP, Chuong LV, Hong Chau T, et al. The prognostic and pathophysiologic role of pro-and antiinflammatory cytokines in severe malaria. J Infect Dis. 1999;180:1288-97.

36. Nie CQ, Bernard NJ, Schofield L, Hansen DS. CD4+ CD25+ regulatory T cells suppress CD4+ T-cell function and inhibit the development of Plasmodium berghei-specific TH1 responses involved in cerebral malaria pathogenesis. Inf Immun. 2007;75:2275-82.

37. Haque A, Best SE, Amante FH, Mustafah S, Desbarrieres L, de Labastida F, et al. CD4+ natural regulatory $T$ cells prevent experimental cerebral malaria via CTLA-4 when expanded in vivo. PLoS Pathog. 2010;6:e1001221.

38. Boström S, Giusti P, Arama C, Persson J, Dara V, Traore B, et al. Changes in the levels of cytokines, chemokines and malaria-specific antibodies in response to Plasmodium falciparum infection in children living in sympatry in Mali. Malar J. 2012;11:109.

39. Healer J, McGuinness D, Carter R, Riley E. Transmission-blocking immunity to Plasmodium falciparum in malaria-immune individuals is associated with antibodies to the gamete surface protein Pfs 230 . Parasitology. 1999;119:425-33.

40. Friedland JS, Ho M, Remick DG, Bunnag D, White NJ, Griffin GE. Interleukin-8 and Plasmodium falciparum malaria in Thailand. Trans R Soc Trop Med Hyg. 1993:87:54-5

41. Robinson LJ, D'Ombrain MC, Stanisic DI, Taraika J, Bernard N, Richards JS, et al. Cellular tumor necrosis factor, gamma interferon, and interleukin-6 responses as correlates of immunity and risk of clinical Plasmodium falciparum malaria in children from Papua New Guinea. Inf Immun. 2009;77:3033-43.

42. Kern P, Hemmer CJ, Van Damme J, Gruss H-J, Dietrich M. Elevated tumor necrosis factor alpha and interleukin-6 serum levels as markers for complicated Plasmodium falciparum malaria. Am J Med. 1989:87:139-43.

43. Guiyedi V, Bécavin C, Herbert F, Gray J, Cazenave P, Kombila M, et al. Asymptomatic Plasmodium falciparum infection in children is associated with increased auto-antibody production, high IL-10 plasma levels and antibodies to merozoite surface protein 3. Malar J. 2015:14:162.

44. Torre D, Speranza F, Giola M, Matteelli A, Tambini R, Biondi G. Role of Th1 and Th2 cytokines in immune response to uncomplicated Plasmodium falciparum malaria. Clin Diagn Lab Immunol. 2002;9:348-51.

45. Biemba G, Gordeuk VR, Thuma P, Weiss G. Markers of inflammation in children with severe malarial anaemia. Trop Med Int Health. 2000;5:256-62.

46. Kurtzhals JAL, Adabayeri V, Goka BQ, Akanmori BD, Oliver-Commey JO, Nkrumah FK, et al. Low plasma concentrations of interleukin 10 in severe malarial anaemia compared with cerebral and uncomplicated malaria. Lancet. 1998;351:1768-72.

47. Rovira-Vallbona E, Moncunill G, Bassat Q, Aguilar R, Machevo S, Puyol L, et al. Low antibodies against Plasmodium falciparum and imbalanced proinflammatory cytokines are associated with severe malaria in Mozambican children: a case-control study. Malar J. 2012;11:181.

48. Li C, Sanni LA, Omer FM, Riley EM, Langhorne J. Pathology of Plasmodium chabaudi chabaudi infection and mortality in interleukin-10-deficient mice are ameliorated by anti-tumor necrosis factor alpha and exacerbated by anti-transforming growth factor $\beta$ antibodies. Infec Immun. 2003;71:4850-6.

49. Hansen DS. Inflammatory responses associated with the induction of cerebral malaria: lessons from experimental murine models. PLoS Pathog. 2012;8:e1003045.

50. Mitchell AJ, Hansen AM, Hee L, Ball HJ, Potter SM, Walker JC, et al. Early cytokine production is associated with protection from murine cerebral malaria. Infect Immun. 2005;73:5645-53.

51. Prakash D, Fesel C, Jain R, Cazenave P-A, Mishra GC, Pied S. Clusters of cytokines determine malaria severity in Plasmodium falciparuminfected patients from endemic areas of Central India. J Infect Dis. 2006;194:198-207.

52. Good MF, Doolan DL. Immune effector mechanisms in malaria. Current opinion in immunology. 1999;11:412-9.

53. Plebanski M, Hill AVS. The immunology of malaria infection. Curr Opin Immunol. 2000;12:437-41.

54. Dodoo D, Omer FM, Todd J, Akanmori BD, Koram KA, Riley EM. Absolute levels and ratios of proinflammatory and anti-inflammatory cytokine production in vitro predict clinical immunity to Plasmodium falciparum malaria. J Infect Dis. 2002;185:971-9.

55. Malaguarnera L, Musumeci S. The immune response to Plasmodium falciparum malaria. Lancet Infect Dis. 2002;2:472-8. 
56. Grzych J-M, Pearce E, Cheever A, Caulada ZA, Caspar P, Heiny S, et al. Egg deposition is the major stimulus for the production of Th2 cytokines in murine schistosomiasis mansoni. J Immunol. 1991;146:1322-7.

57. de Oliveira Fraga LA, Torrero MN, Tocheva AS, Mitre E, Davies SJ. Induction of type 2 responses by schistosome worms during prepatent infection. J Infect Dis. 2010;201:464-72.

58. Wammes LJ, Hamid F, Wiria AE, Wibowo H, Sartono E, Maizels RM, et al. Regulatory $T$ cells in human lymphatic filariasis: stronger functional activity in microfilaremics. PLoS Negl Trop Dis. 2012;6:e1655.

59. Nausch N, Midzi N, Mduluza T, Maizels RM, Mutapi F. Regulatory and activated T cells in human Schistosoma haematobium infections. PLoS One. 2011;6:e16860.

60. Sabin EA, Araujo MI, Carvalho EM, Pearce EJ. Impairment of tetanus toxoid specific Thl-like immune responses in humans infected with Schistosoma mansoni. J Infect Dis. 1996:173:269-72.

61. Kullberg MC, Pearce EJ, Hieny SE, Sher A, Berzofsky JA. Infection with Schistosoma mansoni alters Th1/Th2 cytokine responses to a non-parasite antigen. J Immunol. 1992;148:3264-70.

62. Elrefaei M, El-sheikh N, Kamal K, Cao H. HCV-specific CD27- CD28- memory T cells are depleted in hepatitis $\mathrm{C}$ virus and Schistosoma mansoni coinfection. Immunol. 2003;110:513-8.

63. Pfeffer K. Biological functions of tumor necrosis factor cytokines and their receptors. Cytokine \& Growth Factor Rev. 2003;14:185-91.

64. He Y-X, Chen L, Ramaswamy K. Schistosoma mansoni, S. haematobium, and S. japonicum: early events associated with penetration and migration of schistosomula through human skin. Exp Parasitol. 2002;102:99-108.

65. Amiri P, Locksley RM, Parslow TG, Sadickt M, Rector E, Ritter D, et al. Tumour necrosis factor a restores granulomas and induces parasite egg-laying in schistosome-infected SCID mice. Nature. 1992;356:604.

66. Cheever AW, Poindexter RW, Wynn TA. Egg laying is delayed but worm fecundity is normal in SCID mice infected with Schistosoma japonicum and S. mansoni with or without recombinant tumor necrosis factor alpha treatment. Infect Immun. 1999;67:2201-8.

67. Haseeb MA, Solomon WB, Palma JF. Schistosoma mansoni: effect of recombinant tumor necrosis factor a on fecundity and [14C]-tyrosine uptake in females maintained in vitro. Comp Biochem Physiol C Pharmacol Toxicol Endocrinol. 1996;115:265-9.

68. Oliveira KC, Carvalho MLP, Venancio TM, Miyasato PA, Kawano T, DeMarco R, et al. Identification of the Schistosoma mansoni TNF-alpha receptor gene and the effect of human TNF-alpha on the parasite gene expression profile. PLoS Negl Trop Dis. 2009:3:e556.

69. Geiger SM. Immuno-epidemiology of Schistosoma mansoni infections in endemic populations co-infected with soil-transmitted helminths: present knowledge, challenges, and the need for further studies. Acta Trop. 2008; 108:118-23.

70. Hegewald J, Gantin RG, Lechner CJ, Huang X, Agosssou A, Agbeko YF, et al. Cellular cytokine and chemokine responses to parasite antigens and fungus and mite allergens in children co-infected with helminthes and protozoa parasites. J Inflamm. 2015;12:5.

71. Hamm DM, Agossou A, Gantin RG, Kocherscheidt L, Banla M, Dietz K, et al. Coinfections with Schistosoma haematobium, Necator americanus, and Entamoeba histolytica/Entamoeba dispar in children: chemokine and cytokine responses and changes after antiparasite treatment. J Infect Dis. 2009;199:1583-91

72. Soboslay PT, Hamm DM, Pfäfflin F, Fendt J, Banla M, Schulz-Key H. Cytokine and chemokine responses in patients co-infected with Entamoeba histolytical dispar, Necator americanus and Mansonella perstans and changes after antiparasite treatment. Microbes Infect. 2006;8:238-47.

73. Metenou S, Dembele B, Konate S, Dolo H, Coulibaly YI, Diallo AA, et al. Filarial infection suppresses malaria-specific multifunctional Th1 and Th17 responses in malaria and filarial coinfections. J Immunol. 2011;186:4725-33.

74. Smits HH, Yazdanbakhsh M. Chronic helminth infections modulate allergenspecific immune responses: Protection against development of allergic disorders? Ann Med. 2007:39:428-39.

75. Smits HH, Everts B, Hartgers FC, Yazdanbakhsh M. Chronic helminth infections protect against allergic diseases by active regulatory processes. Curr Allergy Asthma Rep. 2010;10:3-12.

76. Sinha S, Qidwai T, Kanchan K, Jha GN, Anand P, Pati SS, et al. Distinct cytokine profiles define clinical immune response to falciparum malaria in regions of high or low disease transmission. Eur Cytokine Netw. 2010;21:232-40.
77. Figueiredo CA, Barreto ML, Rodrigues LC, Cooper PJ, Silva NB, Amorim LD et al. Chronic intestinal helminth infections are associated with immune hyporesponsiveness and induction of a regulatory network. Infect Immun. 2010;78:3160-7.

78. Geiger SM, Massara CL, Bethony J, Soboslay PT, Carvalho OS, Corrêa-Oliveira R. Cellular responses and cytokine profiles in Ascaris lumbricoides and Trichuris trichiura infected patients. Parasite Immunol. 2002;24:499-509.

79. Weatherhead J, Cortes AA, Sandoval C, Vaca M, Chico M, Loor S, et al. Comparison of cytokine responses in Ecuadorian children infected with Giardia, Ascaris, or both parasites. Am J Trop Med Hyg. 2017;96:1394-9.

80. Sokhna C, Le Hesran J-Y, Mbaye PA, Akiana J, Camara P, Diop M, et al. Increase of malaria attacks among children presenting concomitant infection by Schistosoma mansoni in Senegal. Malar J. 2004;3:43.

81. Spiegel A, Tall A, Raphenon G, Trape J-F, Druilhe P. Increased frequency of malaria attacks in subjects co-infected by intestinal worms and Plasmodium falciparum malaria. Trans R Soc Trop Med Hyg. 2003;97:198-9.

82. Diallo TO, Remoué F, Schacht AM, Charrier N, Dompnier JP, Pillet S, et al. Schistosomiasis co-infection in humans influences inflammatory markers in uncomplicated Plasmodium falciparum malaria. Parasite Immunol. 2004;26:365-9.

83. Sangweme DT, Midzi N, Zinyowera-Mutapuri S, Mduluza T, Diener-West M, Kumar N. Impact of schistosome infection on Plasmodium falciparum malariometric indices and immune correlates in school age children in Burma Valley, Zimbabwe. PLoS Negl Trop Dis. 2010;4:e882.

84. Lemaitre M, Watier L, Briand V, Garcia A, Le Hesran JY, Cot M. Coinfection with Plasmodium falciparum and Schistosoma haematobium: additional evidence of the protective effect of schistosomiasis on malaria in Senegalese children. Am J Trop Med Hyg. 2014;90:329-34.

85. Briand V, Watier L, JY LEH, Garcia A, Cot M. Coinfection with Plasmodium falciparum and Schistosoma haematobium: protective effect of schistosomiasis on malaria in Senegalese children? Am J Trop Med Hyg 2005;72:702-7.

86. Shapiro AE, Tukahebwa EM, Kasten J, Clarke SE, Magnussen P, Olsen A, et al. Epidemiology of helminth infections and their relationship to clinical malaria in southwest Uganda. Trans R Soc Trop Med Hyg. 2005;99:18-24.

87. Adegnika AA, Kremsner PG. Epidemiology of malaria and helminth interaction: a review from 2001 to 2011. Curr Opin HIV AIDS. 2012;7:221-4.

88. Lyke KE, Dabo A, Arama C, Daou M, Diarra I, Wang A, et al. Reduced T regulatory cell response during acute Plasmodium falciparum infection in Malian children co-infected with Schistosoma haematobium. PLoS One. 2012;7:e31647.

89. Lyke KE, Dabo A, Sangare L, Arama C, Daou M, Diarra I, et al. Effects of concomitant Schistosoma haematobium infection on the serum cytokine levels elicited by acute Plasmodium falciparum malaria infection in Malian children. Inf Immun. 2006;74:5718-24.

90. Ateba-Ngoa U, Adegnika AA, Zinsou JF, Kassa RFK, Smits H, MassingaLoembe $M$, et al. Cytokine and chemokine profile of the innate and adaptive immune response of Schistosoma haematobium and Plasmodium falciparum single and co-infected school-aged children from an endemic area of Lambaréné, Gabon. Malar J. 2015:14:94.

91. Sánchez-Arcila JC, Perce-da-Silva D, Vasconcelos MPA, Rodrigues-da-Silva RN, Pereira VA, Aprígio CJL, et al. Intestinal parasites coinfection does not alter plasma cytokines profile elicited in acute malaria in subjects from endemic area of Brazil. Mediators Inflamm. 2014;2014:857245.

92. Formby B. Immunologic response in pregnancy. Its role in endocrine disorders of pregnancy and influence on the course of maternal autoimmune diseases. Endocrinol Metab Clin North Am. 1995;24:187-205.

93. Chaouat G, Menu E, Clark DA, Dy M, Minkowski M, Wegmann TG. Control of fetal survival in CBA x DBA/2 mice by lymphokine therapy. J Reprod Fertil. 1990:89:447-58

94. Vassiliadis S, Tsoukatos D, Athanassakis I. Interferon-induced class II expression at the spongiotrophoblastic zone of the murine placenta is linked to fetal rejection and developmental abnormalities. Acta Physiol Scand. 1994;151:485-95.

95. Jamieson DJ, Theiler RN, Rasmussen SA. Emerging infections and pregnancy. Emerg Infect Dis. 2006;12:1638-43.

96. Suguitan AL Jr, Leke RG, Fouda G, Zhou A, Thuita L, Metenou S, et al. Changes in the levels of chemokines and cytokines in the placentas of women with Plasmodium falciparum malaria. J Infect Dis. 2003;188:1074-82.

97. Megnekou R, Lissom A, Bigoga JD, Djontu JC. Effects of pregnancyassociated malaria on T Cell cytokines in Cameroonian women. Scand J Immunol. 2015;81:508-14. 
98. Egwunyenga AO, Ajayi JA, Nmorsi OP, Duhlinska-Popova DD. Plasmodium/ intestinal helminth co-infections among pregnant Nigerian women. Mem Inst Oswaldo Cruz. 2001;96:1055-9.

99. Clark CE, Fay MP, Chico ME, Sandoval CA, Vaca MG, Boyd A, et al. Maternal helminth infection is associated with higher infant immunoglobulin A titers to antigen in orally administered vaccines. J Infect Dis. 2016;213:1996-2004.

100. Kabyemela ER, Muehlenbachs A, Fried M, Kurtis JD, Mutabingwa TK, Duffy PE. Maternal peripheral blood level of IL-10 as a marker for inflammatory placental malaria. Malar J. 2008;7:26.

101. Bostrom S, Ibitokou S, Oesterholt M, Schmiegelow C, Persson JO, Minja D, et al. Biomarkers of Plasmodium falciparum infection during pregnancy in women living in northeastern Tanzania. PLoS One. 2012;7:e48763.

102. Wilson NO, Bythwood T, Solomon W, Jolly P, Yatich N, Jiang $Y$, et al. Elevated levels of IL-10 and G-CSF associated with asymptomatic malaria in pregnant women. Infect Dis Obstet Gynecol. 2010;2010. doi: https://doi.org/ 10.1155/2010/317430.

103. Ifeanyichukwu MO, Okamgba OC, Amilo Gl, Nwokorie EA. Peripheral parasitaemia and its association with plasma cytokines levels in malariainfected pregnant women in Aba, Abia State, Nigeria. Afr J Infect Dis. 2017;11:54-61

104. Farah IO, Langoi D, Nyaundi J, Hau J. Schistosome-induced pathology is exacerbated and Th2 polarization is enhanced during pregnancy. In Vivo. 2007;21:599-602

105. Elliott AM, Kizza M, Quigley MA, Ndibazza J, Nampijja M, Muhangi L, et al. The impact of helminths on the response to immunization and on the incidence of infection and disease in childhood in Uganda: design of a randomized, double-blind, placebo-controlled, factorial trial of deworming interventions delivered in pregnancy and early childhood [ISRCTN32849447]. Clin Trials. 2007;4:42-57.

106. Tweyongyere R, Mawa PA, Ngom-Wegi S, Ndibazza J, Duong T, Vennervald $B J$, et al. Effect of praziquantel treatment during pregnancy on cytokine responses to schistosome antigens: results of a randomized, placebocontrolled trial. J Infect Dis. 2008;198:1870-9.

107. Mpairwe $H$, Tweyongyere $\mathrm{R}$, Elliott A. Pregnancy and helminth infections. Parasite Immunol. 2014;36:328-37.

108. Wammes LJ, Hamid F, Wiria AE, May L, Kaisar MMM, Prasetyani-Gieseler MA et al. Community deworming alleviates geohelminth-induced immune hyporesponsiveness. Proc Natl Acad Sci USA. 2016;113:12526-31.

109. Bustinduy AL, Sutherland LJ, Chang-Cojulun A, Malhotra I, DuVall AS, Fairley JK, et al. Age-stratified profiles of serum IL-6, IL-10, and TNF-a cytokines among Kenyan children with Schistosoma haematobium, Plasmodium falciparum, and other chronic parasitic co-infections. Am J Trop Med Hyg. 2015;92:945-51

110. Oladele VS, Awobode HO, Anumudu Cl. Subtle morbidities associated with malaria co-infection with schistosomiasis among children in South-West Nigeria. Afr J Med Med Sci. 2014;43:125-35.

111. Afacan NJ, Fjell CD, Hancock RE. A systems biology approach to nutritional immunology - focus on innate immunity. Mol Aspects Med. 2012;33:14-25.

112. Hooper LV, Littman DR, Macpherson AJ. Interactions between the microbiota and the immune system. Science. 2012;336:1268-73.

113. An D, Oh SF, Olszak T, Neves JF, Avci FY, Erturk-Hasdemir D, et al. Sphingolipids from a symbiotic microbe regulate homeostasis of host intestinal natural killer T cells. Cell. 2014;156:123-33.

114. Garrett WS, Lord GM, Punit S, Lugo-Villarino G, Mazmanian SK, Ito S, et al. Communicable ulcerative colitis induced by T-bet deficiency in the innate immune system. Cell. 2007;131:33-45.

115. McKenney EA, Williamson L, Yoder AD, Rawls JF, Bilbo SD, Parker W. Alteration of the rat cecal microbiome during colonization with the helminth Hymenolepis diminuta. Gut Microbes. 2015;6:182-93.

116. Wu S, Li RW, Li W, Beshah E, Dawson HD, Urban JF Jr. Worm burdendependent disruption of the porcine colon microbiota by Trichuris suis infection. PLoS One. 2012;7:e35470

117. Houlden A, Hayes KS, Bancroft AJ, Worthington JJ, Wang P, Grencis RK, et al Chronic Trichuris muris infection in C57BL/6 mice causes significant changes in host microbiota and metabolome: effects reversed by pathogen clearance. PLoS One. 2015;10:e0125945.

118. Wammes LJ, Hamid F, Wiria AE, May L, Kaisar MM, Prasetyani-Gieseler MA, et al. Community deworming alleviates geohelminth-induced immune hyporesponsiveness. Proc Natl Acad Sci USA. 2016;113:12526-31.

119. WHO. Malaria vaccine: WHO position paper - January 2016. Wkly Epidemiol Rec. 2016;4:33-52.
120. Perlman RL. Mouse models of human disease: an evolutionary perspective. Evol Med Public Health. 2016:2016:170-6.

121. Shanks N, Greek R, Greek J. Are animal models predictive for humans? Philos Ethics Humanit Med. 2009;4:2.

122. Looareesuwan S, Sjostrom L, Krudsood S, Wilairatana P, Porter RS, Hills F, et al. Polyclonal anti-tumor necrosis factor-alpha Fab used as an ancillary treatment for severe malaria. Am J Trop Med Hyg. 1999;61:26-33.

123. Mordmuller BG, Metzger WG, Juillard P, Brinkman BM, Verweij CL, Grau GE, et al. Tumor necrosis factor in Plasmodium falciparum malaria: high plasma level is associated with fever, but high production capacity is associated with rapid fever clearance. Eur Cytokine Netw. 1997;8:29-35.

124. Shear HL, Marino MW, Wanidworanun C, Berman JW, Nagel RL. Correlation of increased expression of intercellular adhesion molecule-1, but not high levels of tumor necrosis factor-alpha, with lethality of Plasmodium yoelii 17XL, a rodent model of cerebral malaria. Am J Trop Med Hyg. 1998;59:852-8.

125. Hoffmann KF, Cheever AW, Wynn TA. IL-10 and the dangers of immune polarization: excessive type 1 and type 2 cytokine responses induce distinct forms of lethal immunopathology in murine schistosomiasis. J Immunol. 2000;164:6406-16.

126. Mwatha JK, Kimani G, Kamau T, Mbugua GG, Ouma JH, Mumo J, et al. High levels of TNF, soluble TNF receptors, soluble ICAM-1, and IFN-gamma, but low levels of IL-5, are associated with hepatosplenic disease in human schistosomiasis mansoni. J Immunol. 1998;160:1992-9.

127. Achidi EA, Apinjoh TO, Mbunwe E, Besingi R, Yafi C, Wenjighe Awah N, et al. Febrile status, malarial parasitaemia and gastro-intestinal helminthiases in schoolchildren resident at different altitudes, in southwestern Cameroon. Ann Trop Med Parasitol. 2008;102:103-18.

128. Zeukeng F, Tchinda VHM, Bigoga JD, Seumen CHT, Ndzi ES, Abonweh G, et al. Co-infections of malaria and geohelminthiasis in two rural communities of Nkassomo and Vian in the Mfou health district, Cameroon. PLoS Neg Trop Dis. 2014;8:e3236

129. Njunda AL, Fon SG, Assob JC, Nsagha DS, Kwenti TD, Kwenti TE. Coinfection with malaria and intestinal parasites, and its association with anaemia in children in Cameroon. Infect Dis Poverty. 2015:4:43.

130. Fernandez-Nino JA, Idrovo AJ, Cucunuba ZM, Reyes-Harker P, Guerra AP, Moncada LI, et al. Paradoxical associations between soil-transmitted helminths and Plasmodium falciparum infection. Trans R Soc Trop Med Hyg. 2012;106:701-8.

131. Degarege A, Animut A, Legesse M, Erko B. Malaria severity status in patients with soil-transmitted helminth infections. Acta Trop. 2009;112:8-11.

132. Degarege A, Animut A, Legesse M, Erko B. Malaria and helminth coinfections in outpatients of Alaba Kulito Health Center, southern Ethiopia: a cross sectional study. BMC Res Notes. 2010;3:143

133. Degarege A, Legesse M, Medhin G, Animut A, Erko B. Malaria and related outcomes in patients with intestinal helminths: a cross-sectional study. BMC Infect Dis. 2012;12:291.

134. Alemu A, Shiferaw $Y$, Ambachew A, Hamid H. Malaria helminth co-infections and their contribution for aneamia in febrile patients attending Azzezo health center, Gondar, Northwest Ethiopia: a cross sectional study. Asian Pac J Trop Med. 2012;5:803-9.

135. Adegnika AA, Ramharter M, Agnandji ST, Ateba Ngoa U, Issifou S, Yazdanbahksh $M$, et al. Epidemiology of parasitic co-infections during pregnancy in Lambarene, Gabon. Trop Med Int Health. 2010;15:1204-9.

136. Hartgers FC, Obeng BB, Kruize YC, Dijkhuis A, McCall M, Sauerwein RW, et al. Responses to malarial antigens are altered in helminth-infected children. J Infect Dis. 2009;199:1528-35.

137. Humphries D, Mosites E, Otchere J, Twum WA, Woo L, Jones-Sanpei H. et al. Epidemiology of hookworm infection in Kintampo North Municipality, Ghana: patterns of malaria coinfection, anemia, and albendazole treatment failure. Am J Trop Med Hyg. 2011;84:792-800.

138. Burdam FH, Hakimi M, Thio F, Kenangalem E, Indrawanti R, Noviyanti $R$, et al. Asymptomatic vivax and falciparum parasitaemia with helminth co-infection: major risk factors for anaemia in early life. PLoS One. 2016;11:e0160917.

139. Righetti AA, Glinz D, Adiossan LG, Koua AY, Niamke S, Hurrell RF, et al. Interactions and potential implications of Plasmodium falciparum-hookworm coinfection in different age groups in south-central Cote d'Ivoire. PLoS Negl Trop Dis. 2012;6:e1889.

140. Yapi RB, Hurlimann E, Houngbedji CA, Ndri PB, Silue KD, Soro G, et al, Infection and co-infection with helminths and Plasmodium among school children in Cote d'Ivoire: results from a National Cross-Sectional Survey. PLoS Negl Trop Dis. 2014;8:e2913. 
141. Koukounari A, Estambale BBA, Njagi JK, Cundill B, Ajanga A, Crudder C, et al. Relationships between anaemia and parasitic infections in Kenyan schoolchildren: a Bayesian hierarchical modelling approach. Int J Parasitol. 2008:38:1663-71.

142. Van Eijk AM, Lindblade KA, Odhiambo F, Peterson E, Rosen DH, Karanja D, et al. Geohelminth infections among pregnant women in rural western Kenya; a cross-sectional study. PLoS Neg Trop Dis. 2009;3:e370.

143. Brooker SJ, Pullan RL, Gitonga CW, Ashton RA, Kolaczinski JH, Kabatereine $\mathrm{NB}$, et al. Plasmodium-helminth coinfection and its sources of heterogeneity across East Africa. J Infect Dis. 2012;205:841-52.

144. Bustinduy AL, Parraga IM, Thomas CL, Mungai PL, Mutuku F, Muchiri EM, et al. Impact of polyparasitic infections on anemia and undernutrition among Kenyan children living in a Schistosoma haematobium-endemic area. Am J Trop Med Hyg. 2013;88:433-40

145. Kepha S, Nuwaha F, Nikolay B, Gichuki P, Edwards T, Allen E, et al. Epidemiology of coinfection with soil transmitted helminths and Plasmodium falciparum among school children in Bumula District in western Kenya. Parasit Vectors. 2015;8:314.

146. Thigpen MC, Filler SJ, Kazembe PN, Parise ME, Macheso A, Campbell $\mathrm{CH}$, et al. Associations between peripheral Plasmodium falciparum malaria parasitemia, human immunodeficiency virus, and concurrent helminthic infection among pregnant women in Malawi. Am J Trop Med Hyg. 2011;84:379-85.

147. Ojurongbe O, Adegbayi AM, Bolaji OS, Akindele AA, Adefioye OA, Adeyeba OA. Asymptomatic falciparum malaria and intestinal helminths co-infection among school children in Osogbo. Nigeria. J Res Med Sci. 2011;16:680-6.

148. Dada-Adegbola HO, Oluwatoba OA, Falade CO. Asymptomatic malaria and intestinal helminth co-infection among children in a rural community in Southwest Nigeria. MWJ. 2013;4:18.

149. Abanyie FA, McCracken C, Kirwan P, Molloy SF, Asaolu SO, Holland CV, et al. Ascaris co-infection does not alter malaria-induced anaemia in a cohort of Nigerian preschool children. Malar J. 2013;12:1.

150. Kinung'hi SM, Magnussen P, Kaatano GM, Kishamawe C, Vennervald BJ. Malaria and helminth co-infections in school and preschool children: a cross-sectional study in Magu district, north-western Tanzania. PLoS One. 2014;9:e86510.

151. Kinung'hi SM, Mazigo HD, Dunne DW, Kepha S, Kaatano G, Kishamawe C, et al. Coinfection of intestinal schistosomiasis and malaria and association with haemoglobin levels and nutritional status in school children in Mara region, northwestern Tanzania: a cross-sectional exploratory study. BMC Res Notes. 2017:10:583.

152. Hillier SD, Booth M, Muhangi L, Nkurunziza P, Khihembo M, Kakande M, et al. Plasmodium falciparum and helminth coinfection in a semiurban population of pregnant women in Uganda. J Infect Dis. 2008;198:920-7.

153. Pullan RL, Kabatereine NB, Bukirwa H, Staedke SG, Brooker S. Heterogeneities and consequences of Plasmodium species and hookworm coinfection: a population based study in Uganda. J Infect Dis. 2011;203:406-17.

154. Rutagwera DG, Tylleskär T. Co-infection with malaria, hookworm and schistosomiasis among school children in Zambezi: a school-based rapid survey. Med J Zambia. 2012;39:18-23.

155. Humphries D, Simms BT, Davey D, Otchere J, Quagraine J, Terryah S, et al. Hookworm infection among school age children in Kintampo North Municipality, Ghana: nutritional risk factors and response to albendazole treatment. Am J Trop Med Hyg. 2013;89:540-8

156. Metenou S, Kovacs M, Dembele B, Coulibaly YI, Klion AD, Nutman TB. Interferon regulatory factor modulation underlies the bystander suppression of malaria antigen-driven IL-12 and IFN- $\gamma$ in filaria-malaria co-infection. Eur J Immunol. 2012;42:641-50.

157. Courtin D, Djilali-Saiah A, Milet J, Soulard V, Gaye O, Migot-Nabias F, et al. Schistosoma haematobium infection affects Plasmodium falciparum-specific $\lg \mathrm{G}$ responses associated with protection against malaria. Parasite Immunol. 2011;33:124-31.

158. Diallo TO, Remoue F, Gaayeb L, Schacht A-M, Charrier N, De Clerck D, et al. Schistosomiasis coinfection in children influences acquired immune response against Plasmodium falciparum malaria antigens. PLoS One. 2010;5: e12764

159. Muok EMO, Mwinzi PNM, Black CL, Carter JM. Childhood coinfections with Plasmodium falciparum and Schistosoma mansoni result in lower percentages of activated T cells and T regulatory memory cells than schistosomiasis only. A. J Trop Med Hyg. 2009;80:475.

\section{Ready to submit your research? Choose BMC and benefit from:}

- fast, convenient online submission

- thorough peer review by experienced researchers in your field

- rapid publication on acceptance

- support for research data, including large and complex data types

- gold Open Access which fosters wider collaboration and increased citations

- maximum visibility for your research: over $100 \mathrm{M}$ website views per year

At BMC, research is always in progress.

Learn more biomedcentral.com/submissions 